DOI: 10.2478/atd-2019-0012

\title{
Parents' Expectation of Mathematics Education and Their Engagement in Education and Homework Habits of Children
}

\author{
Yasemin Deringöl* \\ Received: July 30, 2019; received in revised form: September 9, 2019; \\ accepted: September 12, 2019
}

\begin{abstract}
:
Introduction: In this study, it was aimed to examine the expectations of elementary and secondary school parents from the mathematics education and their engagements in the education and the mathematics homework habits of their children.

Methods: The research data was collected by "A Scale to Determine Parents' Expectation from Mathematics Education", "Mathematics Homework Behavior Scale" and the "Personal Information Form" prepared by the researcher. The data of this study executed and conducted by survey model was analyzed by SPSS 16 .

Results: In the study, it is revealed that the expectations of parents from Mathematics education and the mathematics homework habit of their children are high. There is no difference based on the levels of the children and parentage status of the parents, regardless of being mother or father, the mathematics homework habit of the children who favor mathematics lesson and at the same time thrive on is more favorable and positive than the ones who do not favor mathematics lesson and at the same time fail to thrive on, the homework habit of the children whom are supported sufficiently in the mathematics lesson is more favorable and positive. Last but not least, there is no correlation between the expectations of the parents from Mathematics education and the homework habits of their children.

Discussion: High expectations of parents from mathematics classes may suggest that they trust their children and their teachers. It may also suggest that they are involved in the education process and that they find it sufficient. Based on the findings of this study, according to which the level of homework habits of the parents' children is high, it can be assumed that the students do their homework willingly and they have no problems with doing their daily homework. Parents' help their children's with homework occasionally to make them feel that they are not alone in this process. Lower expectations from their children and lower engagement of parents
\end{abstract}

\footnotetext{
* Yasemin Deringöl, İstanbul Üniversitesi-Cerrahpaşa, Istanbul, Turkey; dyasemin@istanbul.edu.tr
} 


\section{Acta Educationis Generalis \\ Volume 9, 2019, Issue 3}

at upper levels may be caused by the fact that they cannot support their children sufficiently due to the complexity of subjects. In elementary schools, since their children are smaller in terms of age, parents may think that their children need more help and they can be more active in education because the subjects in elementary school are not as complicated as in higher classes. The math homework habits do not differ according to the education level of students' but, based on the scores, we can say that they are more favourable in the elementary school since the children are younger and besides, in Turkey, children are assigned homework more regularly and the homework habits start to emerge at the elementary school level. Just depending on the scores, it is interesting to note that the expectations of fathers from mathematics education and their engagement in the process are higher than those of mothers. This may suggest that the expectations of fathers from their children may be due to the higher goals they set for them and perhaps since they are more perfectionist, they are more involved in the children's education than mothers. To like a lesson, can be considered a precondition for doing the assigned homework more willingly. Children do their homework more willingly in the courses at which they consider themselves successful. That is why the results of this study are not surprising. The homework habits of the children sufficiently supported in mathematics are expected to be more favourable. The expectations of parents from mathematics lesson were not related to their children's homework habits. The absence of homework habits, in the parents' expectation from mathematics lesson, may be due to not getting a clear answer from the parents with respect to the question whether homework should be assigned in education or not.

Limitations: These research and data collection tools used are limited only by the thoughts of parents of primary and middle school students in Turkey.

Conclusions: The child, being aware that he is not alone in the process, will be more confident if he knows that there is a family support behind him in overcoming mathematics.

Key words: Mathematics, elementary school, secondary school, expectation from Mathematics education, homework habit.

\section{Introduction}

In order to improve students' learning skills, educators need to build a bridge with parents to provide solid education for all students (Price, 1997). Parents can be considered as the cornerstone of the social institutions that schools are affected and affect the most. Teachers, students and parents can be listed among the elements that make up the existing education system, ensure the continuity of the system and add vital value to the system. In order to achieve the desired level of success in the education system, these three must cooperate for common purposes throughout the learning process. Since parents are one of the most 


\section{Acta Educationis Generalis \\ Volume 9, 2019, Issue 3}

important elements of the education process, their engagement in the children's education process is necessary. In order for parents to engage in their children's education effectively, they should have expectations from their children's education, keep good communication with the school as well as their children, take part in school activities and help their children in their learning activities (Hacısalihoğlu-Karadeniz, Aksu, \& Topal, 2012).

Jeynes (2007) examined 41 studies related to family engagement and again in the meta-analysis studies of Fan \& Chen (2001), it was found that there was a positive correlation between the academic success of their children and their parents' engagement in education. At the same time, when academic achievement was examined according to a specific indicator (e.g. mathematics grade), a stronger impact value was found (Fan \& Chen, 2001). In another study which examined 51 studies published between 1995 and 2002, it was concluded that parents' engagement in their children's education was also related to students' achievement (Henderson \& Mapp, 2002). Many studies have concluded that there is a strong and positive correlation between parents' engagement and expectations in their children's education and the academic success of the children (Akbaba-Altun, 2009; Anderson \& Minke, 2007; Ayral et al., 2012; Akay, 2012; Barnová, Tamášová, \& Krásna, 2019; Bean, Bush, McKenry, \& Wilson, 2003; Beydoğan, 2006; Cai, Moyer, \& Wang, 1999; Çelenk, 2003; Dinç, 2017; Englund et al., 2004; Erbay, 2013; Gonzales-Pienda et al., 2002; Gutman \& Midgley, 2000; Keçeli-Kaysıl1, 2008; Kotaman, 2008; Loomans, 2014; Schickedanz, 2003; Patrikakou, 2008; Peressini, 1998; Toldson \& Lemmons, 2013; Werf, Creemers, \& Guldemond, 2001; Yenilmez, 2006). Research has shown that parents who engage in the education of their children contribute not only to high academic achievement, but also to positive behavior and emotional development of the children (Booth \& Dunn, 1996; Eccles \& Harold, 1993; Cai, 2003). Parents' engagement in the children's education, which aims to increase the success of children, includes the acquisition of many skills from learning the abilities related with the specific subject to the development of appropriate relationships within the family (Keçeli-Kaysıll, 2008).

An efficient collaboration and reciprocal interaction established between the family and school during the educational process have substantial contributions to the mathematics achievements of the student. Child receives his/her primary education in the family and parents are the first teachers of their children. Therefore, as the acquisition of mathematical notion and skills of the child getting introduced with the mathematics in the very early period commences by the informal education directly received in the family, the rise of the success rate of the child within the next educational process is directly proportional to the level of awareness of the family. Engagement of the families in the educational process is expressed as expectations of the families with respect to the mathematics achievements of their child, engagement of families in the school 


\section{Acta Educationis Generalis \\ Volume 9, 2019, Issue 3}

activities and interaction between the school-family and the student (Hacısalihoğlu-Karadeniz, Aksu, \& Topal, 2012).

Although many different types of parental involvement have been defined in students' education, definitions can be grouped into two categories (Greenwood \& Hickman, 1991; Xu et al., 2010): 1) parent engagement in various school activities aimed at strengthening the general school program and 2) assisting the child in school learning tasks at home. Parents' help with learning tasks at home can be interpreted as supporting studies at home. Every day, when students return home from school, teachers give homework to reinforce the learned knowledge, prepare for the next day's lessons or help them acquire new knowledge. The quality and quantity of homework varies from teacher to teacher. Despite these differences in teacher's system, there are differences among students according to their performance such as doing their homework or not. There are students who do their homework regularly as well as students who do not do their task regularly (Kapıkıran \& Kıran, 1999). It is emphasized by the educators that if the activities done in the school are not supported by the preparation, practice and homework activities that the parents contribute to, learning cannot be achieved fully (Albayrak, Yıldız, Berber, \& Büyükkasap, 2004). Although teachers have the main responsibility for the assignment, the parents also have important responsibilities in this process since the homework is usually done outside the school. In addition, one of the objectives of the assignment is to ensure parent engagement in the educational process (Ersoy \& Anagün, 2009). Through homework, parents give their attention to the children and help them (Hill, 1992). Parents and teachers can collaborate in this process by reinforcing good practice habits both at home and at school. When parents and teachers work together, children can develop lifelong healthy studying and practicing habits (Patrikakou, 2008). Parents help children by actively playing a role in controlling their children's homework, or passively in creating a quiet and positive atmosphere (Hong, Milgram, \& Perkins, 1995; Jong, Westerhof, \& Creemers, 2000).

Assigning homework to students is a highly controversial issue. Many studies mention the negative aspects of the homework assignments. It is claimed that the use of homework as a tool is a burden on house and family life, that homework prevents the children to enjoy their childhood, spoil family life and abolish their natural curiosity (Haddock, 2006). Aloia (2003) expresses concern that homework may cause frustration, stress, reduced time spent with the family, to live and experience their childhood. Kohn (2006) mentions the research that supports the idea that homework has a very little educational value and may have a negative impact on learning for young children (14 years and under). In addition Ginsburg (2007) states that adding homework to a child's program may cause mental fatigue in the children in a home environment. In spite of all these negative thoughts, homework reinforces what the students have learned and is necessary for practicing and giving the student a sense of responsibility 


\section{Acta Educationis Generalis \\ Volume 9, 2019, Issue 3}

(Baltaoğlu, Sucuoğlu \& Öztürk, 2017); reasoning, conducting research and investigation, working on their own, working as a group, gaining the habit of reading books (Şen \& Gülcan, 2012); teaching lifelong personal characteristics such as self-discipline, independence and responsibility, and enabling them to work at their own skill levels and discover their own interests (Kapıkıran \& Kiran, 1999); contributing to the development of independent learning skills of students and provides the continuity of learning at home in parallel with their lessons at school (Acar, Ersoy, Eser, \& Akar-Vural, 2013); it should be remembered that it helps to develop many skills such as using modern technologies in accessing information, producing new information out of the information obtained and using their creativity (Turan-Özpolat, Karakoç, \& Kara, 2017). Both parents and teachers help in children's homework, increase the depth and quality of learning, provides more motivation, responsibility, sense of purpose and confidence, and can contribute to improving student achievement (Hatch, 1998). According to the teachers' point of view, the role of homework is to develop skills and grasp the concepts, to extend the course work to extracurricular time and to develop a sense of responsibility, and according to students point of view homework has functions such as to improve understanding of mathematics concepts, to review and apply the gained knowledge, to develop problem solving skills, to prepare for exams, to understand mistakes, to evaluate learning process and to extend knowledge of mathematics (Kaur, 2011). In 43 of the 50 studies examined for Cooper's (1989) meta-analysis it was found that there is a positive correlation between time spent on homework and success. Fan, Xu, Cai, He, and Fan (2017), found a positive correlation between achievement on mathematics and homework habits of students in a meta-analysis study that reviews the researches on math and science homework between 1986 and 2015. There are many research results showing that homework improves success (Arıkan, 2017; Büyüktokatlı, 2009; Cheema \& Sheridan, 2015; Cool, 1991; Iflazoğlu \& Hong, 2012; Kapıkıran \& Kiran, 1999; Kitsantas, Cheema, \& Ware, 2011; Nuez et al., 2015; Özcan \& Göğebakan-Yıldız, 2017; Pezdek, Berry, \& Renno, 2002; Rudman, 2014; Thelen, 2008).

In addition to daily assignments starting from the first year, project assignments are delivered on a weekly or monthly basis (Acar, Ersoy, Eser, \& Akar-Vural, 2013). The common type of homework given by teachers in Turkey is determined according to the subject. In math classes, assignments usually consist of a large number of problems to be solved by students that are often found in books and journals and homework on the social subjects is in the form of reading and repetitive writing. Such homework types make the student get bored of the homework easily and prevent learning new and correct information (Kapıkıran \& Kiran, 1999). In mathematics course, where the necessity to practice is more in terms of content, students are expected to use symbols, numbers, formulas or rules that need to be known to solve the problem situations 


\section{Acta Educationis Generalis \\ Volume 9, 2019, Issue 3}

given to them and to be practical in this subject. In Turkey, in the first year of the elementary school mathematics curriculum does not require homework and homework given in the second academic year constitute the daily tasks the students need to do. The math course, which requires much of the practice and contains more abstract and symbolic information compared to other courses, may need to be supplemented with homework. Therefore, classroom teachers who aim the learning process to continue at home and increase mathematical comprehension, assign homework to their students (Acar, Ersoy, Eser, \& AkarVural, 2013).

When the literature in the field is examined, it was found that much research has been made about math homework (Acar et al., 2013; Arıkan, 2017; Cheema \& Sheridan, 2015; Fa et al., 2017; Fernandez-Alonso et al., 2015; Hong et al., 2016; Jong, Westerhof, \& Creemers, 2000; Kapıkıran \& Kıran, 1999; Kitsantas, Cheema, \& Ware, 2011; O'Sullivan, 2008; Özcan \& Erktin, 2013; Özcan \& Göğebakan-Yıldız, 2017; Pelletier, 2005; Pezdek, Berry, \& Renn, 2002; Thelen, 2008; Trautwein et al., 2002; Voorhis, 2011; Zhu \& Leung, 2012) and the engagement of parents in the educational process and their expectations from mathematics education (Akay, 2012; Anderson, 1997; Ayral et al., 2012; Aytekin, Baltac1, Altunkaya, Kıymaz, \& Y1ldı, 2016; Cai, Moyer, \& Wang, 1999; Cai, 2003; Civil et al., 2008; Erbay, 2013; Kutluca \& Aydın, 2010; Nyabuto \& Njoroge, 2014; Peressini, 1998; Şahin-Doğruer, 2014; Tsui, 2005; Yenilmez, 2006; Yenilmez, Özer, \& Yıldız, 2006). However, as it can be seen, no study has been found that examines the expectations from and engagement of parents in mathematics education and their children's math homework habits. Figuring out this gap in the field, in this study, we aimed to examine the expectations from and engagement of elementary and secondary school students' parents in mathematics education and their children's math homework habits. For this purpose, the following research problems were sought:

1. What are the parents' expectations from mathematics education and their engagement in education and how their children's math homework habits are?

2. Do the parents' expectations and engagement in mathematics education and their children's math homework habits differ according to the level of their children?

3. Do the parents' expectations and engagement in mathematics education and their children's math homework habits differ according to parents such as being a mother/father?

4. Do their parents' expectations from mathematics education and their engagement in education and their children's math homework habits differ according to children's liking the subject or not, in children's success and whether they are sufficiently supported or not in this course? 


\section{Acta Educationis Generalis \\ Volume 9, 2019, Issue 3}

5. Is there a meaningful correlation between the parents' expectations from mathematics education, their engagement in education and the children 's homework habits?

\section{Method}

In terms of data, the study has a quantitative paradigm. As the main objective was to determine parents' expectation from mathematics education and mathematics homework behaviors of their children, the study was conducted as a correlational survey model. As stated by Karasar (2004), the survey model aims at "describing a situation existing in the past or recently as it is."

\subsection{Sample}

The sample of the study is consisted of parents of 243 students studying in Istanbul between 2017-2018 academic years and selected by simple random sampling method. The distribution of parents in the study group is given below.

Table 1

Distribution of Parents

\begin{tabular}{lcccccc}
\hline & \multicolumn{2}{c}{ Mother } & \multicolumn{2}{c}{ Father } & \multicolumn{2}{c}{ Total } \\
& $n$ & $\%$ & $n$ & $\%$ & $n$ & $\%$ \\
\hline Elementary & 111 & 63.8 & 63 & 36.2 & 174 & 71.6 \\
Secondary & 43 & 62.3 & 26 & 37.7 & 69 & 28.4 \\
Total & 154 & 63.4 & 89 & 36.6 & 243 & 100.0 \\
\hline
\end{tabular}

The sample consisted of 243 parents, 174 of whom (71.6\%) were elementary and $69(28.4 \%)$ were secondary school parents. $154(63.4 \%)$ of the parents were mothers; 89 (36.6\%) were fathers.

\subsection{Data collection tools}

In the study, the "Personal Information Form", "A Scale to Determine Parents' Expectation from Mathematics Education" and "Mathematics Homework Behavior Scale" was used as data collection tools.

Personal Information Form: The first data collection tool is the "Personal Information Form" developed by the researcher. This form consists of demographic information about parents and questions about whether or not their children like the course, whether or not they are successful in mathematics, and whether or not they are sufficiently supported in this course. 


\section{Acta Educationis Generalis \\ Volume 9, 2019, Issue 3}

A Scale to Determine Parents' Expectation from Mathematics Education (PEMEC): This scale developed by Aytekin, Baltac1, Altunkaya, Kiymaz, and Y1ldiz (2016) consists of 15 items and 3 sub-dimensions. These sub-dimensions are: "Conceptual Understanding and Expectation of Student Active Education", "Expectation of Positive Attitude and Behavior Acquisition", and "Expectation of Rule-Weighted Instruction where Teacher is Authority." This scale, which was developed to reveal and evaluate student parents' expectations about mathematics course, was graded between 'very little' and 'very high'. The maximum score is 75 and the minimum score is 15 . The internal consistency coefficient of this scale was .84; and .78 was found in this research.

Mathematics Homework Behavior Scale (MHBS): This scale was developed by Özcan and Erktin (2013) to evaluate students' homework habits. To express the level of engagement in a 15-item two-factor scale called "Willingness of the Child" and "Importance of Homework" Always (5), often (4), occasional (3), rarely (2) and never (1) 5-point Likert type rating is used. The internal consistency coefficient of the scale was .91; and .79 was found in this research.

\subsection{Data collection}

The measurement tools selected in accordance with the objectives of the study were distributed to the parents at the families gathering organization of the school. The forms were sent through the children to the parents who were not reached. Data collection tools filled in by the parents and the data was evaluated by the statistical computer program.

\subsection{Data analysis}

The statistical analyses of the measurement tools were conducted using SPSS 16.0. Before starting the analyses, Kolmogorov-Smirnov test was conducted to test the suitability of the data to normal distribution, and at the same time, the Skewness-Kurtosis values of the scores were evaluated. Since the level of significance was found to lower than .05 according to the Kolmogorov-Smirnov test results, and the skewness coefficient was between +2.0 and -2.0 as reported by George and Mallery (2010), it was observed that the data showed normal distribution, and parametric tests were used. Accordingly, in data analysis, Independent-Samples t-Test, and Pearson Moment Correlation tests were applied and the results were calculated.

\section{Findings}

Depending on the variables of expectations of elementary and secondary school parents from mathematics education and their engagement in education and mathematics homework habits of their children are presented below. The findings of the first sub-problem are given in Table 2. 
Table 2

Mean Scores from Scales

\begin{tabular}{lcll}
\hline Scale & $N$ & Mean & Ss \\
\hline PEMEC & 243 & 3.79 & .52 \\
MHBS & 243 & 2.43 & .53 \\
\hline
\end{tabular}

The scores obtained from "A Scale to Determine Parents' Expectation from Mathematics Education (PEMEC)" and "Mathematics Homework Behavior Scale (MHBS)" are shown in Table 2.

In order to determine the levels according to the scores obtained from the scales, the interval width of the scale was calculated by using the formula "array width / number of groups" $(4 / 5=0.80)$ (Tekin, 1993). Arithmetic mean intervals of the scale; were determined as 1.00-1.79 'Very low', 1.80-2.59 'Low', 2.60-3.39 'Medium', 3.40-4.19 'High', 4.20-5.00 'Very high'. These averages were used for "A Scale to Determine Parents Expectation from Mathematics Education (PEMEC)", however since the expressions of "Mathematics Homework Behavior Scale (MHBS)" were negative, a reverse evaluation was made. In other words, it is determined as 1.00-1.79 'Very high', 1.80-2.59 'High', 2.60-3.39 'Medium', 3.40-4.19 'Low', 4.20-5.00 'Very low'. As a conclusion, it was found that the expectations of the parents from the mathematics education were high and their children's mathematics homework habits were found to be high.

The findings of the second problem are given in Table 3 .

Table 3

Independent Sample t-Test Results of the Scores Obtained from Scales According to the Education Level of the Parents' Children

\begin{tabular}{llrrrrr}
\hline Scale & $\begin{array}{l}\text { Education } \\
\text { Levels }\end{array}$ & $N$ & Mean & $S$ & $t$ & $p$ \\
\hline PEMEC & Elementary & 174 & 57.24 & 8.11 & 1.036 & .301 \\
& Secondary & 69 & 56.07 & 7.43 & & \\
MHBS & Elementary & 174 & 36.06 & 7.82 & - & .134 \\
& Secondary & 69 & 37.79 & 8.67 & 1.505 & \\
\hline
\end{tabular}

"A Scale to Determine Parents' Expectation from Mathematics Education (PEMEC)" ( $\mathrm{t}=1.036, \mathrm{p}>.05)$ and "Mathematics Homework Behavior Scale (MHBS)" ( $\mathrm{t}=-1.505, \mathrm{p}>.05)$. There is no significant difference between the total scores of the scales and the education levels of children of the parents of the study. However, if we evaluate the scores that were obtained, it is seen that the 


\section{Acta Educationis Generalis \\ Volume 9, 2019, Issue 3}

expectations of the parents of elementary school students $(=57.24)$ are higher than the expectations of the parents of secondary school students $(=56.07)$. When the mathematics homework habits of children were examined according to the scores obtained, it was found that mathematics homework habits of elementary school students $(=36.06)$ were slightly more positive than mathematics homework habits of secondary school students $(=37.79)$ (Table 3$)$. The findings of the third problem are given in Table 4.

Table 4

Independent Sample t-Test Results of the Scores Obtained from Scales According to Parents Such as Being Either Mother or Father

\begin{tabular}{lcrcccc}
\hline Scale & Parents & \multicolumn{1}{c}{$N$} & Mean & $S$ & $t$ & $p$ \\
\hline PEMEC & Mother & 154 & 56.74 & 7.85 & -.437 & .663 \\
& Father & 89 & 57.20 & 8.10 & & \\
MHBS & Mother & 154 & 36.67 & 8.38 & .293 & .770 \\
& Father & 89 & 36.35 & 7.60 & & \\
\hline
\end{tabular}

“A Scale to Determine Parents' Expectation from Mathematics Education (PEMEC)" ( $\mathrm{t}=-.437, \mathrm{p}>.05)$ and "Mathematics Homework Behavior Scale (MHBS)" ( $\mathrm{t}=.293, \mathrm{p}>.05)$. There is no significant difference between the total scores of the scales and the parents being either mother or father of the study. However, if we evaluate the scores that were obtained it is seen that the fathers' expectations from mathematics education $(=57.20)$ are slightly higher than the expectation of mothers from mathematics education $(=56.74)$. When the "Mathematics Homework Behavior Scale" scores were evaluated, the fathers statement about their children's homework habits $(=36.35)$ are more positive compared to mothers' $(=36.67)$ statement (Table 4$)$.

However, according to the scores obtained, it is seen that the expectations of fathers from mathematics education $(=57.20)$ are higher than the expectation of mothers from mathematics education $(=56.74)$.

The findings of the fourth problem are given in Tables 5, 6 and 7.

Table 5

Independent Sample t-Test Results of the Scores Obtained from Scales According to Question "Does your child like mathematics?"

\begin{tabular}{lcrcccc}
\hline Scale & Liking Math & \multicolumn{1}{c}{$N$} & Mean & $S$ & $t$ & $p$ \\
\hline PEMEC & Yes & 211 & 56.63 & 8.13 & -1.363 & .174 \\
& No & 32 & 58.68 & 6.26 & & \\
\hline
\end{tabular}




\begin{tabular}{llrrrrr}
\hline \multirow{2}{*}{ MHBS } & Yes & 211 & 35.31 & 7.10 & -6.675 & \\
& No & 32 & 44.75 & 9.42 & & $.000^{* *}$ \\
\hline
\end{tabular}

There is a significant difference between total scores of "Mathematics Homework Behavior Scale (MHBS) $(\mathrm{t}=-6.675, \mathrm{p}<.01)$ and the answers given to the question "Does your child like mathematics?". Since the "Mathematics Homework Behavior Scale (MHBS)" consists of adverse (negative) items, the mathematics homework habits of those with low scores are positive and according to this; homework habits of those who favor mathematics found to be more positive than those who does not. There is no significant difference between "A Scale to Determine Parents' Expectation from Mathematics Education (PEMEC)" $(\mathrm{t}=-1.363, \mathrm{p}>.05)$ and the children favoring mathematics or not (Table 5).

Table 6

Independent Sample t-Test Results of the Scores Obtained from Scales According to Question "Is your child successful in mathematics class?"

\begin{tabular}{lcccccc}
\hline Scale & Successful & $N$ & Mean & $S$ & $t$ & $p$ \\
\hline PEMEC & Yes & 209 & 56.59 & 7.94 & -1.522 & .129 \\
& No & 34 & 58.82 & 7.66 & & \\
MHBS & Yes & 209 & 35.24 & 7.17 & -6.826 & $.000^{* *}$ \\
& No & 34 & 44.61 & 8.81 & & \\
\hline
\end{tabular}

There is a significant difference between total scores of "Mathematics Homework Behavior Scale (MHBS)" scale $(\mathrm{t}=-6.826, \mathrm{p}<.01)$ and the answers given to the question 'Is your child successful in mathematics class?' Since the "Mathematics Homework Behavior Scale (MHBS)" consists of adverse (negative) items, the mathematics homework habits of those with low scores are positive and according to this; homework habits of those who are successful in mathematics found to be more positive than those who are not. There is no significant difference between "A Scale to Determine Parents' Expectation from Mathematics Education (PEMEC)" ( $\mathrm{t}=-1.522, \mathrm{p}>.05)$ and whether the children are successful in mathematics (Table 6). 


\section{Acta Educationis Generalis \\ Volume 9, 2019, Issue 3}

Table 7

Independent Sample t-Test Results of The Scores Obtained from Scales According to Question "Is your child sufficiently supported in mathematics?"

\begin{tabular}{lcccccc}
\hline Scale & Support & $N$ & Mean & $S$ & $t$ & $p$ \\
\hline PEMEC & Yes & 141 & 57.09 & 8.62 & .438 & .662 \\
& No & 102 & 56.64 & 6.89 & & \\
MHBS & Yes & 141 & 34.98 & 7.38 & -3.655 & $.000^{* *}$ \\
& No & 102 & 38.73 & 8.54 & & \\
\hline
\end{tabular}

There is a significant difference between total scores of "Mathematics Homework Behavior Scale (MHBS)" scale $(\mathrm{t}=-3.655, \mathrm{p}<.01)$ and the answers given to the question "Is your child sufficiently supported in mathematics?" Since the "Mathematics Homework Behavior Scale (MHBS)" consists of adverse (negative) items, the mathematics homework habits of those with low scores are positive and according to this; homework habits of those who are supported sufficiently found to be more positive than those who are not. There is no significant difference between "A Scale to Determine Parents' Expectation from Mathematics Education (PEMEC)" ( $\mathrm{t}=.438, \mathrm{p}>.05)$ and whether or not the children are sufficiently supported in mathematics (Table 7).

The findings of the fifth problem are given in Table 8 .

Table 8

Pearson Product Moment Correlation Analysis Results of the Scores from A Scale to Determine Parents' Expectation from Mathematics Education (PEMEC) and Mathematics Homework Behavior Scale (MHBS)

\begin{tabular}{lccc}
\hline Scales & $N$ & $r$ & $p$ \\
\hline PEMEC & & & \\
MHBS & 243 & .044 & .494 \\
\hline
\end{tabular}

As it can be seen from Table 8, there is no significant correlation between "A Scale to Determine Parents' Expectation from Mathematics Education (PEMEC)" and "Mathematics Homework Behavior Scale (MHBS)" ( $\mathrm{r}=.044$; $\mathrm{p}>.05)$ 


\section{Acta Educationis Generalis \\ Volume 9, 2019, Issue 3}

\section{Discussion and conclusion}

The first result of this study, in which the expectations of elementary and secondary school parents from mathematics education and their engagement in education and the children's mathematics homework habits were examined, the expectations of parents from mathematics education are high and the mathematics homework habits of their children are high. High expectations of parents from mathematics classes may suggest that they have faith in their children and their teachers. It may also suggest that they are involved in the education process and that they find themselves sufficient. When we examine the studies about the expectations of parents and especially their engagement in education; it is observed that in the study conducted by Dinç (2017), there is a significant positive correlation between the perception of parent engagement and the success of the students based on the grade point averages. In other words, as the parent's engagement in the children's education process increases, the students' success in the lessons increases. In the study in which Cai (2003) examined the role of parents in their children's mathematics education in the United States and the People's Republic of China, it was found that parental involvement was correlated with students' mathematical problem-solving performance and that Chinese families have more influence on their children's mathematics success than American families. In the experimental master's thesis, in which Akay (2012) examines the success level of the mathematics class of 5th grade students with parents' engagement in performance tasks, it is concluded that the students' success level of mathematics increased in the experimental group in which there is parents' engagement in favor of the final test. In a study in which Tsui (2005) examined 8th grade students' mathematics success level, the expectations of the parents from education and their engagement, it is found that the children of the Chinese parents who keep good communication with their children and have high expectations from them in terms of success, are more successful compared to American students whose parents have less expectations in terms of success. Finally, in another study, which was conducted by Cai, Moyer, and Wang (1999) with the parents of 220 secondary school students, it was concluded that the mathematics success and the attitudes of the children towards mathematics are better where the parents are more supportive and participative. As a result, in many studies such as this study, it is concluded that the engagement of parents in education is important for the success of the students (Akbaba-Altun, 2009; Erbay, 2013; Korkmaz \& Bektaş, 2014; Maton, Hrabowski, \& Greif, 1998; Yenilmez, 2006).

As it is observed in all academic studies, naturally some students are willing to do their homework, while others are unwilling (Duru \& Çöğmen, 2016). Depending on the findings of this study according to which the homework habits of the children of the parents are high, it can be considered that the students do their homework willingly and they have no problem about doing their daily homework. Parents' help with their children's homework from time to time will 


\section{Acta Educationis Generalis \\ Volume 9, 2019, Issue 3}

make them feel that they are not alone in this process. Parents' engagement seems to be part of the solution to the improvement of the students' homework practice skills (Nyabuto \& Njoroge, 2014; Rajoo \& Velo, 2015). In the research of Karaca and Gür (2004), most of the parents (56\%) who live in villages stated that they could not help their children in their homework due to their lack of information. While the majority $(65 \%)$ of the parents in the village thinks that the pass grade in mathematics is satisfactory, the parents in the city do not consider it as such (53\%). Nyabuto and Njoroge (2014) concluded that the performance of mathematics in elementary school students in Kenya is influenced by parenting factors and that parents have responsibilities such as providing learning materials in mathematics, helping them to do their homework, following up their school work, and attending school meetings and functions. In a study conducted by Pezdek, Berry and Renno (2002) the parents of the 4, 5, and 6 grade students were asked the performance of the children in math according to their homework practices at home and it was seen that those who helped their children at home correctly predicted their children's math performances. In the study conducted by Fan, Xu, Cai, He, and Fan (2017) the mathematics and science homework were examined which were done between 1986 and 2015. In the field of mathematics, the correlation between homework and success was found to be stronger among elementary and high school students than the secondary school students. In addition to this the correlation between homework and success found to be the strongest in studies involving US students and weakest in studies involving Asian students. In another study conducted with 143 third year students, Pelletier (2005) found a positive correlation between homework performance and achievement in mathematics. Similarly, based on data from 7451 secondary school students in Spain, Fernandez-Alonso et al. (2015) found that the frequency of homework, the time and efforts spent on homework are in positive correlation with mathematics achievement. In a study conducted by Zhu and Leung (2012) where the TIMSS 2003 data of the eighth grade students examined, it was observed that homework has a positive effect on success and although the time spent on daily mathematics homework have a significant positive effect on the students' TIMSS results, it has no effect on the frequency of homework given. In the study of Jong, Westerhof, and Creemers (2000), a positive correlation was found between mathematics success and homework habits of 1394 Dutch secondary school students. However, the frequency and the time spent on homework does not affect success. In most of the researches it is concluded that assignments positively affect the success of the mathematics class and the status of homework habits are positive (Arıkan, 2017; Cheema \& Sheridan, 2015; Kapıkıran \& Kıran, 1999; Kitsantas, Cheema, \& Ware, 2011; Özcan \& Göğebakan-Yıldız, 2017; Pezdek, Berry, \& Renno, 2002; Thelen, 2008).

In the study, when the analysis was made according to the education levels of children, no significant difference was found for both scales. However, 


\section{Acta Educationis Generalis \\ Volume 9, 2019, Issue 3}

according to the scores obtained, the expectations and engagement of the parents of elementary school students in mathematics education are high and their children's math homework habits are slightly more positive. Lower expectations from their children and lower engagement of parents at upper levels may be due to the fact that they cannot support their children sufficiently due to the complexity of the subjects. In elementary school, since their children are smaller in terms of age, parents may think that the children need more help and they can be more active in education because the subjects in elementary school are not as complicated as the higher classes. In the study of Albayrak, Y1ldız, Berber, and Büyükkasap (2004), it was concluded that both elementary and secondary school students were mostly supported by their parents because they could not do extracurricular activities on their own. According to the data, it was concluded that the courses that the students require the most help from the parents were Mathematics, Turkish, Life Science, Social Studies, Science, Foreign Language, respectively. In the study of Kotaman (2008), as in this study, no significant difference was found between the education level of the children and the engagement of parents in the education process. In the study in which Büyüktokatlı (2009) asked teachers' opinions about homework practices in elementary education, most students especially first grade students mentioned that they need the support of parents but according to the interviews teachers made with the parents, they indicated that the parents are unconscious about helping the children. In the study of Özcan (2016), where the beliefs and engagement of parents in mathematics learning processes were examined and the majority (75\%) had undergraduate and postgraduate degree, again, parental awareness, engagement, support and positive attitudes decreased slightly in secondary school however parents follow up the success level of the children more frequently. In the study conducted by Yenilmez (2006), in-class engagement levels of the parents were higher while the students were in the lower classes and lower in the upper classes. There are numerous studies that support this result (Ayral et al., 2012; Fa et al., 2017; Henderson \& Mapp, 2002; Simon, 2000).

The math homework habits do not differ according to the education level of students' but just depending on the scores we can say that it is more positive and higher in the elementary school since the children are younger and besides in Turkey children are assigned homework more regularly and the homework habits start to emerge at the elementary school level. Cooper (1989) concluded that the correlation between the time spent on homework in elementary school and achievement is weaker than in high school in 50 studies. Interestingly, the correlation increases with age. Duru and Çöğmen (2017) show that mathematics is the most popular lesson for both parents and elementary school students. For the secondary school students, parents stated that mathematics was very much liked, and students also liked science and technology homework. In the thesis of O'Sullivan (2008), similar to the results of this study, it was concluded that 


\section{Acta Educationis Generalis \\ Volume 9, 2019, Issue 3}

parents provide more homework assistance to younger students and those with low achievement, and they help elementary school students more than secondary school students and their children's homework habits lead to an increase in their success in mathematics.

In this study, no significant difference was found between the parents of being mother- father and the scale scores. However, according to the scores obtained, we can say that the expectations of fathers from mathematics education are higher than the expectation of mothers and fathers' statement about their children's math homework habits was more positive than mothers. Just depending on the scores, it is interesting to note that the expectations of fathers from mathematics education and their engagement in the process are higher than those of the mothers. This may suggest that the expectations of fathers from their children may be due to the higher goals they set for them and perhaps since they are more perfectionist, they are more involved in the children's education than mothers. In the study conducted by Dinç (2017), it was observed that the parents' perception of family engagement did not differ statistically according to their gender, close correlations and age. In contrast, Yenilmez (2006) found that mothers' engagement in mathematics education process was higher than that of fathers. Again Şahin-Doğruer (2014) examined the mathematics engagement of the children of three seventh grade mothers and concluded that there is a correlation between mothers' engagement in education and their children's success. As can be seen, with different results in the literature, this subject is open to discussion. Another finding of the study which is about the mathematical homework habits of their children, it is noteworthy that fathers talk more positively about their children's homework habits than mothers do because in Turkey during children's study time fathers are at work, in other words they are not at home while mothers are comparatively more at home. Therefore, mothers are the ones who will be able to better observe their children's study habits. That is why the fathers' more positive opinion may indicate that they do not have the full control of this situation. In the study of Şen and Gülcan (2012), in which the parents of fourth and fifth grade students were asked their opinions about homework, it was seen that mothers are the ones who were mostly assisting the children in their homework and parents generally give support in their homework. In another study examining mothers' help with their children's homework, it was concluded that $15-20 \%$ of mothers of fifth grade students showed weaknesses and also had significant difficulties that could be used to encourage children's learning (Hyde et al., 2006). In a research on determining the emotions that are expressed by mothers in the homework process and their children's success, positive interest, compassion, joy and pride were stated among the most remarkable positive emotions of mothers and children, while the most remarkable emotions expressed were tension, frustration and distress. It was concluded that the tension between mothers and children's emotions, which reflect the social aspects of doing homework, was associated with lower 


\section{Acta Educationis Generalis \\ Volume 9, 2019, Issue 3}

performance and positive interest, humor and pride were associated with better performance (Else-Quest, Hyde, \& Hejmadi, 2008). As can be seen, mothers play a more active role in the homework of their children.

The parents were asked the question "Does your child like mathematics?" and their answers were examined according to the total scores scale. Accordingly, it was found that mathematics homework habits of children who favor the class were more positive than those who did not. It is not surprising that children's math homework habits are related to their interest. To like a lesson can be effective in doing the homework of that class more willingly. In Duru and Çöğmen's (2017) research on parents' opinion about the homework of elementary and secondary school students, it was found that among the important factors that determine students' opinions about homework is liking/ disliking the homework/ lesson, finding it boring or fun, feelings about the teacher, feeling self-sufficient/ insufficient takes place. According to the answers of the question "Does your child like mathematics?" There was no significant difference in the expectations of families from mathematics education. Ayral et al. (2012) investigated the effect of parental engagement on students' mathematics achievement in contrast to this study it was found that there was a significant positive increase in affective dimensions with the increase of parental engagement level.

There is a significant difference between the answers given by the parents to the question "Is your child successful in mathematics?" and the total scores of the scale. This difference is that children's (successful in mathematics) homework habits are more positive than those who are not. As mentioned earlier, there is a correlation between the success of the child in mathematics and the desire to do homework. Children do the homework of the courses more willingly at which they consider themselves successful. That is why the result of this study is not surprising. Turan Özpolat, Karakoç and Kara (2017) stated that homework assignments have an effect on success and homework in general has a positive effect on student achievement, and parents that help the student for doing the homework will get better results and avoiding the homework would affect the student's performance negatively. Özcan and Göğebakan-Yıldız (2017) examined parents' views and engagement of their children's mathematics homework and found out that they believe the home assignments have a positive effect on mathematics achievement and it was also mentioned that they support their children in mathematics assignments. In Trautwein, Köller, Schmitz, and Baumert's (2002) study which examined 125 seventh grade students, it is concluded that the mathematics achievement of those are higher who do their homework regularly by following the new knowledge and procedures that they have gained daily or preparing for future lessons and reviewing the previous lessons. At the same time, short term assignments have positive effects on success. As mentioned before, it is possible to come across studies that show that the success and doing homework is positive and in the same direction (Fa et al., 


\section{Acta Educationis Generalis \\ Volume 9, 2019, Issue 3}

2017; Jong, Westerhof, \& Creemers, 2000; Pezdek, Berry, \& Renno, 2002; Zhu $\&$ Leung, 2012). Another finding of the same problem is that the difference between parents' expectations from mathematics education and whether their children succeed or not is not significant. Ayral et al. (2012), found that there is a significant correlation between parental engagement level and students' mathematics achievement levels.

Finally, the parents were asked the question "Is your child sufficiently supported in mathematics class?" and the difference between their answers and the total scores of the scale was examined. Accordingly, homework habits of children who were sufficiently supported in mathematics lesson were found to be more positive. The homework habits of the children are expected to be higher and positive who are thought to be sufficiently supported in mathematics. Because the child who is supported will be interested in this subject in every way and as mentioned previously, the course which is of interest will be done more willingly. In the study of Şen and Gülcan (2012), parents state that teachers should provide sufficient time and support for students to do their homework on their own by giving daily homework instead of project-performance assignments. Parents stated that they should help with homework. Karaca and Gür (2004), in their research on the engagement of families in village and city settlements in mathematics teaching, stated that the parents in both places were willing to help but they did not know how, but the parents in the village taught the lecture given in the class by the teacher is sufficient. Parents in every segment, especially the ones in the village stated that they had difficulty in solving mathematics questions and explaining the subject to their children. Another finding of the study to the same question is that there is no significant difference in the expectations of parents from mathematics education. Although the teacher or parent support should be related to expectations with the mathematics education, it is interesting that the difference in this study is not significant.

Interestingly, the final finding of the study is that there is no correlation between parents' expectations from mathematics education and their children's math homework habits. In other words, the expectations of parents from mathematics lesson were not related to their children's homework habits. The absence of homework habits in the parents' expectation from mathematics lesson may be due to not getting a clear answer from the parents with respect to the question whether homework should be assigned in education or not. In the semiexperimental longitudinal study of 153 elementary school students and parents were observed by Voorhis (2011) and it is found that students with family engagement were significantly higher in mathematics achievement and at the same time showed more positive feelings and attitudes towards mathematics homework. In the study by Shumow and Miller (2001) it is concluded that parents help more to their children with low performances in their homework than those who perform well, and that parents of successful children engage 


\section{Acta Educationis Generalis \\ Volume 9, 2019, Issue 3}

more in school and mothers' engagement is higher than fathers. As can be seen, it is not possible to reach a clear conclusion about the parents' engagement in mathematics education and their children's homework habits.

In conclusion, the child, being aware that s/he is not alone in the process, will be more confident if s/he knows that there is a family support behind him/her in overcoming mathematics (Yenilmez, 2006). Therefore, it is considered that parents' engagement in mathematics education should be as high as their expectations they should support their children in their homework in out of school learning situations and take an active role accordingly. As a similar study, differentiating the research group and examining students and teachers can also contribute to the literature in this field.

\section{References}

Acar, E., Ersoy, E., Eser, N., \& Akar-Vural, R. (2013). The relationship of the problems of ballet dancers in Turkey with the education process after active dance life. Boğaziçi University Journal of Education, 30(2), 47-85.

Akay, Y. (2012). The effect of performance tasks with parental involvement on the elementary 5th grade students' achievements and attitudes in mathematics lesson (Master's thesis). Izmir: Dokuz Eylül University.

Akbaba-Altun, S. (2009). An investigation of teachers', parents', and students' opinions on elementary students' academic failure. Elementary Education Online, 8(2), 567-586.

Albayrak, M., Yıldız, A., Berber, K., \& Büyükkasap, E. (2004). Parents' opinions about extracurricular activities in elementary school and related student behaviors. Kastamonu Education Journal, 12(1), 13-18.

Aloia, S. (2003). Teacher assessment of homework. Academic Exchange Quarterly, 7, 71-77.

Anderson, A. (1997). Families and Mathematics: A study of parent-child interactions. Journal for Research in Mathematics Education, 28(4), 484511.

Anderson, K. J., \& Minke, K. M. (2007). Parent involvement in education: Toward an understanding of parents' decision making. The Journal of Educational Research, 100(5), 311-323.

Arıkan, S. (2017). The relationship between homework and mathematics achievement in Turkey according to TIMSS 2011. International Journal of Eurasia Social Sciences, 8(26), 256-276.

Ayral, M. et al. (2012). The effect of parent participation on students' mathematics achievement. IV. International Educational Research Congress, 56-64.

Aytekin, C., Baltac1, S., Altunkaya, B., Kıymaz, Y., \& Yıldız, A. (2016). A scale to determine parents' expectation from Mathematics education (PEME): 


\section{Acta Educationis Generalis \\ Volume 9, 2019, Issue 3}

Development, reliability and validity. Ahi Evran University Journal of Education, 17(3), 397-411.

Baltaoğlu, M. G., Sucuoğlu, H., \& Öztürk, N. (2017). Classroom teachers' opinions about homeworks. Journal of Education and Future, 11, 95-109.

Barnová, S., Tamášová, V., \& Krásna, S. (2019). The role of resilience in coping with negative parental behaviour. Acta Educationis Generalis, 9(2), 93106. https://doi.org/10.2478/atd-2019-0010

Bean, R. A., Bush, K. R., McKenry, P. C., \& Wilson, S. M. (2003). The Impact of parental, support, behavioral control, and psychological control on the academic achievement and self-esteem of African-American and European American Adolescents. Journal of Adolescent Research, 18(5), 523-541.

Beydoğan, H. Ö. (2006). The models and approaches about the parent involvement in education process. Gazi University Journal of Gazi Education Faculty, 7(1), 75-90.

Booth, A. \& Dunn, J. F. (1996). Family school links: How do they affect educational outcomes? Hillsdale, NJ: Erlbaum.

Büyüktokatlı, N. (2009). Examination of teachers' opinions about homework applications in primary education (Master's thesis). Konya, Turkey: Selçuk University.

Cai, J., Moyer, J. C., \& Wang, N. (1999). Parental roles in students' learning of mathematics: An exploratory study. Research in Middle Level Education Quarterly, 22(3) 1-18. http://dx.doi.org/10.1080/10848959.1999.11670147

Cai, J. (2003). Investigating parental roles of students' learning of mathematics from a cross-national perspective. Mathematics Education Research Journal, 15(2), 87-106.

Cheema, J. R., \& Sheridan, K. (2015). Time spent on homework, mathematics anxiety and mathematics achievement: Evidence from a US sample. Issues in Educational Research, 25, 246-259.

Civil, M., Díez-Palomar, J., Menéndez, J. M., \& Acosta-Iriqui, J. (2008). Parents' interactions with their children when doing mathematics. ALM International Journal, 3(2a), 41-58.

Cool, V. A., \& Keith T. Z. (1991). Testing a model of school learning: Direct in direct effects on academic achievement. Contemporary Educational Psychology, 16, 28-44.

Cooper, H. (1989). Homework. White Plains, NY: Longman.

Çelenk, S. (2003). The Prerequisite for School Success: Home-School Cooperation. Elementary Education Online, 2(2), 28-34.

Dinç, F. (2017). Relationship between level of participation in education and student success (Master's thesis without thesis), Denizli, Turkey: Pamukkale University.

Duru, S., \& Çöğmen, S. (2016). The validity and reliability study of the Homework Motivation Scale. International Periodical for the Languages, 


\section{Acta Educationis Generalis \\ Volume 9, 2019, Issue 3}

Literature and History of Turkish or Turkic, 11(3), 1049-1064. http://dx.doi.org/10.7827/TurkishStudies.9395

Duru, S., \& Çöğmen, S. (2017). Views of primary and secondary school students and their parents on homework. Elementary Education Online, 16(1), 354365. http://dx.doi.org/10.17051/io.2017.76577

Eccles, J. S., \& Harold, R. D. (1993). Parent-school involvement during the early adolescent years. Teachers College Record, 94, 568-587.

Else-Quest, N. M., Hyde, J. S., \& Hejmadi, A. (2008). Mother and child emotions during mathematics homework. Mathematical Thinking and Learning, 10, 5-35.

Englund, M. M., Luckner, A. E., Whaley, G. J. L., \& Egeland, B. (2004). Children's achievement in early elementary school: Longitudinal effects of parental involvement, expectations, and quality of assistance. Journal of Educational Psychology, 96(4), 723-730.

Erbay, H. N. (2013). Family relationship with mathematics achievement of functionality: South correlations Turkey Comparison (Master's thesis). Istanbul, Turkey: Marmara University.

Ersoy, A., \& Anagün, Ş. S. (2009). Elementary teachers' views about homework process in science and technology course. Necatibey Faculty of Education Electronic Journal of Science and Mathematics Education, 3(1), 58-79.

Fan, X., \& Chen, M. (2001). Parental involvement and students' academic achievement: A meta-analysis. Educational Psychology Review, 13(1), 122.

Fan, H., Xu, J., Cai, Z., He, C., \& Fan, X. (2017). Homework and students' achievement in math and science: A 30-year meta-analysis, 1986-2015. Educational Research Review, 20, 35-54.

Fernandez-Alonso, R., Suarez-Alvarez, J., \& Muniz, J. (2015). Adolescents' homework performance in mathematics and science: Personal factors and teaching practices. Journal of Educational Psychology, 107, 1075-1085.

George, D., \& Mallery, M. (2010). SPSS for windows step by step: A simple guide and reference. 17.0 update. Boston: Pearson.

Ginsburg, K. R. (2007). The importance of play in promoting healthy child development and maintaining strong parent-child bonds. Pediatrics, 119(1), 182-191.

Gonzales-Pienda, J. A. et al. (2002). A structural equation model of parental involvement, motivational and attitudinal characteristics, and academic achievement. The Journal of Experimental Education, 70(3), 257-287.

Greenwood, G. E., \& Hickman, C. W. (1991). Research and practice in parental involvement: Implications for teacher education. The Elementary School Journal, 9(3), 279-288.

Gutman, L. M., \& Midgley, C. (2000). The role of protective factors in supporting the academic achievement of poor African American students 


\section{Acta Educationis Generalis \\ Volume 9, 2019, Issue 3}

during the middle school transition. Journal of Youth and Adolescence, 29, 233-248.

Hacısalihoğlu-Karadeniz, M., Aksu, H. H., \& Topal, T. (2012). The effect of the process of parents' participation on the primary-school 1st grade students' math success. Journal of National Education, 19, 232-245.

Haddock, V. (2011). After Years of Teachers piling it on, there's a new movement to abolish homework. The San Francisco Chronicle.

Hatch, T. (1998). How community action contributes to achievement. Educational Leadership, 55(8), 16-19.

Hill, T. A. (1992). Homework: How effective? How much to assign? The need for clear policies. OSSC Bulletin, 36(1), 1-41.

Henderson, A. T., \& Mapp, K. L. (2002). A new wave of evidence: The impact of school, family, and community connections on student achievement. Austin, TX: Southwest Educational Development Laboratory.

Hong, E., Milgram, R. M., \& Perkins, P. G. (1995). Homework style and homework behavior of Korean and American children. Journal of Research and Development in Education, 4, 197-207.

Hong, E., Mason, E., Peng, Y., \& Lee, N. (2016). Effects of homework motivation and worry anxiety on homework achievement in mathematics and English. Educational Research and Evaluation, 1(7), 1-24. http://dx.doi.org/10.1080/13803611.2015.1131721

Hyde, J. S., Else-Quest, N. M., Alibali, M. W., Knuth, E., \& Romberg, T. (2006). Mathematics in the home: Homework practices and mother-child interactions doing mathematics. Journal of Mathematical Behavior, 25, 136-152.

Iflazoğlu, A., \& Hong, E. (2012). Relationships of homework motivation and preferences to homework achievement and attitudes in Turkish students. Journal of Research in Childhood Education, 26, 57-72.

Jeynes, W. H. (2007). The relationship between parental involvement and urban secondary school student academic achievement a meta-analysis. Urban Education, 42(1), 82-110.

Jong, R., Westerhof, K. J., \& Creemers, B. P. M. (2000). Homework and student Math achievement in junior high schools. Educational Research and Evaluation: An International Journal on Theory and Practice, 6(2), 130157.

Kapıkıran, Ş., \& Kıran, H. (1999). The effect of the homework on the student's academic success. Pamukkale University Journal of Education, 5, 54-60.

Karaca, D., \& Gür, H. (2004). Participation of families in village and urban settlements in mathematics teaching. V. National Science and Mathematics Education Congress. Available at http://www.fedu. metu.edu.tr/ufbmek5/b_kitabi/b_kitabi.htm

Karasar, N. (2005). Scientific research method. Ankara: Nobel Broadcast Distribution. 


\section{Acta Educationis Generalis \\ Volume 9, 2019, Issue 3}

Kaur, B. (2011). Mathematics homework: A study of three grade eight classrooms in Singapore. International Journal of Science and Mathematics Education, 9, 187-206.

Keçeli-Kaysıll, B. (2008). Parent involvement to improve academic achievement. Ankara University Faculty of Educational Sciences Journal of Special Education, 9(1), 69-83.

Kitsantas, A., Cheema, J., \& Ware, H. W. (2011). Mathematics achievement: The role of homework and self-efficacy beliefs. Journal of Advanced Academics, 22, 310-339.

Kohn, A. (2006). The truth about homework. Education Week, 26(2), 44-52.

Korkmaz, P., \& Bektaş, M. (2014). The Effect of the Use of the Parent Teacher Information Guide for $2^{\text {nd }}$ Grade Mathematics Lesson on the Parents' Awareness. III. Proceedings of the Congress of Educational Research in Sakarya, (pp. 66-73).

Kotaman, H. (2008). The level of participation of Turkish parents' children in education. Journal of Uludag University Faculty of Education, 21(1), 135149.

Kutluca, T., \& Aydin, M. (2010). Interest, Attitudes and Support towards Families' Mathematics Education. Family and Society, 6(22), 65-78.

Loomans, M. G. S. (2014). Parent involvement that supports children academically and promotes the development of independence (Master's thesis), University of Wisconsin.

Marchant, G. J., Paulson, S. E., \& Rothlisberg, B. A. (2001). Relations of middle school students' perceptions of family and school contexts with academic achievement. Psychology in the Schools, 38(6), 505-519.

Maton, K. I., \& Hrabowski, F. A. (1998). Preparing the way: A qualitative study of high-achieving African American Males and the role of the family. American Journal of Community Psychology, 26(4), 639-668. http://dx.doi.org/10.1023/A:1022197006900

Nuez, J. C., Suárez, N., Rosário, P., Vallejo, G., Valle, A., \& Epstein, J. L. (2015). Relationships between perceived parental involvement in homework, student homework behaviors, and academic achievement: Differences among elementary, junior high, and high school students. Metacognition Learning, 10(3), 375-406.

Nyabuto, A. N., \& Njoroge, P. M. (2014). Parental involvement on pupils' performance in mathematics in public primary schools in Kenya. Journal of Educational and Social Research, 4(1), 19-26. http://dx.doi.org/10.5901/ jesr.2014.v4n1p19

O'Sullivan, R. (2008). The effect of parental involvement with mathematics homework on early elementary and junior high school students (Dissertation thesis). New York: The City University of New York. 


\section{Acta Educationis Generalis \\ Volume 9, 2019, Issue 3}

Özcan, Z. Ç., \& Ertkin, E. (2013). Mathematics Homework Behavior Scale: Reliability and validity study. Boğaziçi University Journal of Education, $31(2), 27-47$.

Özcan, B. N. (2016). Investigation of parents' beliefs and participation in their children's math learning process. The Journal of International Education Science, 8, 105-117.

Özcan, B. N. \& Göğebakan-Yıldız, D. (2017). Parents' opinions about mathematics homeworks and role and involvement on their child's math homework. Journal of TUBAV Science, 10(4), 58-70.

Patrikakou, E. N. (2008). The power of parent involvement: Evidence, ideas, and tools for student success. Chicago Academic Development Institute, DePaul University.

Pelletier, R. (2005). The predictive power of homework assignments on student achievement in grade three (Doctoral dissertation). Miami, Florida: Florida International University.

Peressini, D. D. (1998). The portrayal of parents in the school mathematics reform literature: Locating the context for parental involvement. Journal for Research in Mathematics Education, 29(5), 555-582.

Pezdek, K., Berry, T., \& Renn, P. A. (2002). Children's mathematics achievement: The role of parents' perceptions and their involvement in homework. Journal of Educational Psychology, 94(4), 771-777.

Price, J. (1997). President's report: Building bridges of mathematical understanding for all children. Journal for Research in Mathematics Education, 27, 603-608.

Rajoo, M., \& Velo, A. (2015). The development of Mathematics Homework Engagement (MHE) Instrument for secondary school students, Malaysia. Review of European Studies, 7(7), 87-96. http://dx.doi.org/10.5539/res.v7n7p87

Rudman, N. P. C. (2014). A review of homework literature as a precursor to practitioner-led doctoral research in a primary school. Research in Education, 91, 12-29.

Schickedanz, J. A. (2003). Family socialization and academic achievement. Journal of Education, 1, 17-34.

Simon, B. (2000). Predictors of high school and family partnerships and the influence of partnerships on student success (unpublished doctoral dissertation). Baltimore, MD: John Hopkins University.

Shumow, L., \& Miller, J. D. (2001). Parents' at home and at school academic involvement with young adolescents. Journal of Early Adolescence, 21(1), 68-92.

Şahin-Doğruer, Ş. (2014). Effects of parental roles in students' mathematical learning: How does the education level of parents effect their involvement? The Eurasia Proceedings of Educational \& Social Sciences (EPESS), 1, 8489. 


\section{Acta Educationis Generalis \\ Volume 9, 2019, Issue 3}

Şen, H. Ş., \& Gülcan, M. G. (2012). Parent's opinions about the homework set for $4^{\text {th }}$ and $5^{\text {th }}$ grades of the primary school. Gazi University Journal of Industrial Arts Education Faculty, 29, 29-41.

Tekin, H. (1993). Measurement and evaluation in education. Ankara: Yarg1 Publishing.

Thelen, S. L. O. (2008). The relationship between mathematics homework and learning in middle-school students: Impact on achievement (Master dissertation of Science in Education), Dominican University of California.

Tsui, M. (2005). Family income, home environment, parenting, and mathematics Achievement of children in China and the United States. Education and Urban Society, 37(3), 336-355. http://dx.doi.org/10.1177/00131245042741 88

Toldson, I. A., \& Lemmons, B. P. (2013). Social demographics, the school environment, and parenting practices associated with parents' participation in schools and academic success among black, Hispanic, and white students. Journal of Human Behavior in the Social Environment, 23(2), 237-255.

Trautwein, U., Köller, O., Schmitz, B., \& Baumert, J. (2002). Do homework assignments enhance achievement? A multilevel analysis in $7^{\text {th }}$ grade mathematics. Contemporary Educational Psychology, 27, 26-50. http://dx.doi.org/10.1006/ceps.2001.1084

Turan-Özpolat, E., Karakoç, B., \& Kara, K. (2017). Evaluation of the teachers and parents view about the homeworks given in the primary school. International Journal of Eurasia Social Sciences, 8(30), 1849-1890.

Werf, G., Creemers, B., \& Guldemond, H. (2001). Improving parental involvement in primary education in Indonesia: Implementation, effects and costs. School Effectiveness and School Improvement, 12(4), 447-466.

Voorhis, F. L. V. (2011). Adding families to the homework equation: A longitudinal study of mathematics achievement. Education and Urban Society, 43(3), 313-338. http://dx.doi.org/10.1177/001312451038023

$\mathrm{Xu}, \mathrm{M}$. et al. (2010). The relationship between parental involvement, selfregulated learning, and reading achievement of fifth graders: A path analysis using the ECLS-K database. Social Psychology of Education, 13(2), 237-269.

Yenilmez, K., Özer, M. N., \& Yıldız, Z. (2006). A study on parents' approaches to and contribution to mathematics education of their children. Eskişehir Osmangazi University Journal of Social Sciences, 7(1).

Yenilmez, K. (2006). The contribution levels of parents to mathematics education in primary education. Abant Izzet Baysal University Journal of Faculty of Education, 6(1), 13-28.

Zhu, Y., \& Leung, F. K. S. (2012). Homework and mathematics achievement in Hong Kong: Evidence from the TIMSS 2003. International Journal of Science and Mathematics Education, 10, 907-925. 